\title{
THE EFFECT OF PENGUIN EXERCISE ON THE ANXIETY LEVELS OF FEMALE STUDENTS WHO EXPERIENCE PREMENSTRUAL SYNDROME
}

\author{
Handoyo Handoyo, Hartati Hartati, Esti Dwi Widayanti
}

Poltekkes Kemenkes Semarang

\begin{abstract}
Premenstrual syndrome includes a variety of abnormal physical, psychological, and emotional symptoms associated with a woman's menstrual cycle. The syndrome can interfere with several aspects of women's lives and lead to a decrease in work productivity and concentration in school, as well as anxiety and depression.

The aim of this study was to determine the effect of Penguin exercise on the anxiety levels of young women who experience premenstrual syndrome. This type of research was Quasi Experimental using pre and post test design with a control group. The population of this study were all 8th grade students at SMP N 9 Purwokerto. The sampling technique was simple random sampling. The instrument used to assess anxiety levels was the Taylor Manifest Anxiety Scale (TMAS) questionnaire. Analysis of the data was performed using Wilcoxon's rank sum test.

The results showed that Penguin exercise had a significant effect on the level of anxiety in the treatment group (value $p=0,000$ ) and there was no significant effect on the control group ( $p$ value $=0.233$ ). The conclusion of this study is that Penguin exercise can affect the anxiety levels of 8th grade female students at SMP N 9 Purwokerto who experience premenstrual syndrome.
\end{abstract}

Keywords: anxiety levels, penguin exercise, premenstrual syndrome.

\section{ABSTRAK}

Premenstrual syndrome merupakan kumpulan gejala fisik, psikologis, dan emosi yang terkait dengan siklus menstruasi perempuan. Keadaan tersebut dapat mengganggu beberapa aspek dalam kehidupannya seperti penurunan produktivitas kerja dan konsentrasi di sekolah, kecemasan hingga depresi bahkan keinginan untuk bunuh diri.

Penelitian ini mempunyai tujuan untuk mengetahui pengaruh Senam Pinguin terhadap tingkat kecemasan remaja putri dalam menghadapi Premenstrual syndrome. Jenis penelitian ini adalah penelitian kuantitatif Quasi Experimental menggunakan desain pre dan post test design with control group. Populasi dalam penelitian ini adalah semua siswi di SMPN 9 Purwokerto. Teknik pengambilan sampel secara simple random sampling.. Instrumen yang digunakan untuk menilai tingkat kecemasan adalah kuisioner Taylor Manifest Anxiety Scale (TMAS). Analisa data menggunakan Uji Wilcoxon Signed Rank Test.

Hasil penelitian menunjukkan ada pengaruh yang signifikan senam Penguin terhadap tingkat kecemasan remaja putri yang mengalami pre mesntrual syndrome pada kelompok perlakuan (nilai $p=$ 0,000 ) dan tidak ada pengaruh pada kelompok kontrol (nilai $p=0,233$ ). Kesimpulan dalam penelitian ini adalah senam Penguin mempunyai pengaruh terhadap tingkat kecemasan remaja putri di SMPN 9 Purwokerto yang mengalami premestrual syndrome.

Kata Kunci: premenstual syndrome, senam penguin, tingkat kecemasan.

Corresponding Author : Handoyo Handoyo

ISSN : 1907-6637

Email : handoyo28@gmail.com

e-ISSN : 2579-9320 


\section{BACKGROUND}

Premenstrual Syndrome (PMS) is a physical, psychological and emotional syndrome that occurs due to a woman's menstrual cycle. It is considered to be a predictable syndrome and commonly happens around two weeks prior to the menstrual period occurring (Prawirohardjo et al., 2011). PMS usually disappears when the bleeding of menstruation starts but it may continue afterwards (Suprayanto, 2010). PMS is a syndrome that occurs prior to the woman's menstrual cycle and disappears when the process of menstruation begins.

PMS is indicated by some signs and symptoms such as stomach cramps, headaches, back pain, intense anger and stress (Elvira, 2010). The common symptoms of PMS are mood swings (rapid change in mood), irritability (likely to become easily annoyed or impatient), a significant increase in appetite, becoming forgetful, having concentration problems, being a 'cry baby' (crying very easily), feeling intensly thirsty, getting pimply, suffering from indigestion, having a red face, palpitations, dizziness and sometimes oedema in the lower extremities (Nurmiaty et al., 2011). The symptoms generally appear for the last 7 10 days before menstruation begins (Nugroho \& Utama, 2014) and they can occur routinely during every woman's menstrual cycle (Ratikasari, 2015).

A study from the American College Obstetricians and Gynaecologists (ACOG) in Sri Lanka in 2012 showed that PMS symptoms were experienced by $65.7 \%$ of teenagers (ACOG, 2012). A study by Delara et al., (2012) reported that in Iran, there were around $98.2 \%$ of women in the range of 18-27 years of age who experienced at least one symptom of PMS on a mild or moderate level. There were $34 \%, 17 \%$ and $13 \%$ of adult women in Japan, Hong Kong and Pakistan respectively who experienced PMS. Few women outside of Asian countries experienced PMS, for example in Brazil it was only (39\%), United States of America (USA) (34\%) and Australia (44\%) (Elvira, 2010).

PMS is considered to have a big impact on work productivity, school activity and interpersonal relationships for the sufferers (Wijayanti, 2015). A survey of a study analysis of the subjective perspective of PMS sufferers regarding PMS by Steiner (2000) in (Suparman \& Sentosa, 2011) showed that PMS interfered with their social activities and work with $46.8 \%$ of the respondents experiencing a mild level, $36 \%$ of respondents experiencing a moderate level, $14.2 \%$ of respondents with a severe level and $2.9 \%$ of respondents getting a very severe level of interference in their social activities.

A study by Borenstein (2004) in (Suparman \& Sentosa, 2011) reported that 436 women experienced lower work productivity when they had PMS. This may be related to the difficulty in concentrating, the decrease in enthusiasm, being forgetful, experiencing irritability and being moody and the decrease in coordination ability. Moreover, the study showed that a few women with PMS were absent from work for at least five working days, which caused a decrease in work productivity by as much as $50 \%$. The study also reported that the rates of interpersonal relationship problems and social activity disturbance at work and school were higher for PMS sufferers (Suparman \& Sentosa, 2011).

PMS can also precipitate a serious depression that can turn into suicide or lead to violence from the women towards themselves or others. Other effects resulting from PMS include women often waking up from sleep with the feeling of anger, anxiety or sadness and, as well as this, women with PMS can experience extreme depression, anger, aggression and anxiety, which may jeopardise their safety and surroundings (Gracia et al., 2011). Ritung \& Olivia, (2018) argued that PMS can also decrease the productivity of teenagers related to their daily activities. The symptoms of PMS can influence their school achievements with regards to experiencing decreased levels of concentration towards the learning process, disruption of communication with friends and higher rates of absences (Pawestri, 2014). A study carried out on female students of SMK (senior high school) Batik 1 Surakarta found that some students sometimes asked permission to 
return home from school or even became unconscious at school when they had PMS. There were almost $10 \%$ of female students each month who were absent from school due to PMS and this affected their school achievements (Pawestri, 2014).

Sidabutar (2012) in Wijayanti, (2015) conducted another study in SMA (senior high school) Hang Tuah 1 Surabaya that reported that in 2011, 22 $(10.31 \%)$ of 143 female students in year two had to stay at the Usaha Kesehatan Sekolah (UKS) room (school clinic room) and $43(30.07 \%)$ went home early or were absent from school when they had PMS and had to leave school activities. Elvira (2010) also stated that menstrual problems were the most major problem amongst Indonesian women. That situation resulted in disturbance to daily activities compared to women who do not experience PMS.

The prevalence of PMS in Indonesia is varied across many areas of Indonesia. In the South of Jakarta, $45 \%$ of SMK's female students were found to experience PMS. In Kudus, $45.8 \%$ of midwifery students suffered from PMS. Female students at senior high schools in Padang and Purworejo experienced PMS as much as $51.8 \%$ and $24.6 \%$ respectively. In Semarang, the total of PMS cases noted were as high as $24.9 \%$ (Wijayanti, 2015). Kusumawati and Finurina (2016) conducted a study in 2014 regarding female medical students in Purwokerto and reported that $53.3 \%$ of them experienced PMS. The study concluded that PMS amongst the respondents was caused by several factors including lifestyle, obesity and anxiety (Kusumawati and Finurina, 2016). Anxiety was found to have a significant correlation with PMS for medical students in Universitas Muhammadiyah Purwokerto (UMP) ( $p=0.001 ; r=0.386)$.

Anxiety is considered to be a normal response to stress (Hawari, 2001) but it may be harmful when it is uncontrolled and disturbs the sufferer's life such as impairing social interactions and causing occupational performance in the workplace as well as decreasing the quality of life. Kemenkes (2013) reported that $6.0 \%$ of Indonesian residents experienced emotional mental problems including anxiety and depression. Women are twice as likely as men to suffer from anxiety (Kemenkes, 2013). A study conducted by (Wijayanti, 2015) depicted that there was a correlation between stress, obesity and exercise and PMS for female students in MAN (senior high school) 1 Metro Lampung Timur. Some of the recommendations that came from the study were to increase the intensity of health education for students regarding PMS, nutritional balance and exercises (Wijayanti, 2015)

Penguin exercise has recently become one of the fun and light exercises amongst teenagers and students in Indonesia. Penguin exercise was originally established during scout activity as a rhyme with fun movements. Due to its unique movements including the hands position, footsteps and circular movements, which are similar to a penguin's style, this exercise has become famous not only amongst students and teenagers but also amongst adults. The exercise is considered to have a relaxed tempo and light movements so that it can be done by all age ranges. The exercise does not require any warm up and can easily be practiced anywhere and at any time. The main aim of Penguin exercise is not only to provide entertainment but also recently it has been discovered that the exercise can be used as a therapy for mind relaxation (Jaya et al., 2018). Therefore, further studies are needed to assess the effectiveness of penguin exercise in reducing anxiety amongst female students who have premenstrual syndrome. Some studies have been done previously with a similar research topic, however those studies have different variable measures compared to this research. Maged et al. (2018) revealed that the performance of swimming, which is an aerobic exercise, could reduce the anxiety experienced due to premenstrual syndrome. Another study by Dehnavi et al. (2018) also found that aerobic exercise is one way to treat premenstrual syndrome because it can reduce the physical symptoms of the syndrome. Although the Penguin exercise movements tend to be 
slow and relaxed, all body parts are considered to be involved so that they may release stress and result in a more refreshed body (Jaya et al., 2018).

\section{METHOD}

A quasi experiment with pre- and post-test design with control group was chosen as the method for this study. The study aimed to investigate the relationship between Penguin exercise and anxiety levels and how the exercise influences anxiety levels. The study was conducted in SMP N (junior high school) 9 Purwokerto and SMP N 1 Kalibagor and involved female students with PMS. The respondents were collected using a simple random sampling technique with some inclusion criteria such as willingness to take part in the research, female students of SMPN 9 Purwokerto, and female students who have had a menstrual period.

All female students were gathered and then divided into two groups: treatment and control group. A pre-test was done to both groups to examine students' anxiety regarding their PMS. The Penguin exercise treatment was then applied to the treatment group as much as three times during three month period while the control group was treated with regular exercise known as Senam Kesehatan Jasmani (SKJ). The Penguin exercise that was given to the treatment group has five exercise movements for 30 minutes, namely wing flap movements, turning the head, turning the body, hands rolling and leg movements. The post-test was then given to both groups to measure the anxiety levels of the PMS-students. The Taylor Manifest Anxiety Scale (TMAS), which consists of 38 questions, was used as an instrument to measure the anxiety levels. The level of anxiety was then divided into three categories. Scores of $(<10), \quad(11-24)$ and (25-38) are categories of mild, moderate and severe depression respectively. Wilcoxon Signed Rank Test was used to analyse the significance level. This study was approved by the ethical committee of Semarang Health Polytechnic No: 124/KEPK/ Poltekkes-Smg/ 2018.

\section{RESULT}

The results are shown in the tables with explanations below:

1. Identifying the anxiety levels of female students in the treatment and control group

Table 1. The anxiety levels of female students in the treatment and control group

\begin{tabular}{lcccccccc}
\hline \multirow{2}{*}{ Anxiety level } & \multicolumn{3}{c}{ Treatment group } & \multicolumn{4}{c}{ Control group } \\
\cline { 2 - 9 } & \multicolumn{3}{c}{ Pre test } & \multicolumn{2}{c}{ Post test } & \multicolumn{2}{c}{ Pre test } & \multicolumn{2}{c}{ Post test } \\
& $\mathbf{f}$ & $\%$ & $\mathbf{f}$ & $\%$ & $\mathbf{f}$ & $\%$ & $\mathbf{f}$ & $\%$ \\
\hline Mild $(<10)$ & 7 & 12,7 & 40 & 72,7 & 13 & 23,6 & 15 & 27,3 \\
Moderate $(11-24)$ & 45 & 81,8 & 14 & 25,5 & 40 & 72,7 & 39 & 70,9 \\
Severe $(25-38$ & 3 & 5,5 & 1 & 1,8 & 2 & 3,7 & 1 & 1,8 \\
\hline \multicolumn{1}{c}{$\mathrm{n}($ sample) } & 55 & 100 & 55 & 100 & 55 & 100 & 55 & 100 \\
\hline
\end{tabular}

Table 1 shows that in the pre-test session, the majority of respondents in the treatment group had a moderate level of anxiety ( 45 students or $81.8 \%$ ) while in the control group it was as many as 40 students $(72.7 \%)$. However, in the post test session the number of respondents had changed either in the treatment or control groups. Mostly respondents had mild anxiety levels i.e. 40 respondents $(72 \%)$ in the treatment group, while in the control group there was an increase slightly to 15 respondents (27. 3\%)

2. The anxiety levels of female students before and after Penguin exercise on the treatment and control group 
Table 2. The anxiety levels of female students before and after Penguin exercise on the treatment and control group

\begin{tabular}{|c|c|c|c|c|c|c|}
\hline \multirow[t]{2}{*}{ Anxiety level } & \multicolumn{3}{|c|}{ Treatment group } & \multicolumn{3}{|c|}{ Control group } \\
\hline & Mean & SD & Min-Max & Mean & SD & Min-Max \\
\hline Before & 19,636 & 6,022 & $8,00-36,00$ & 14,709 & 5,533 & $6,00-29,00$ \\
\hline After & 12,381 & 4,424 & $6,00-27,00$ & 15,163 & 6,584 & $7,00-34,00$ \\
\hline n (sample) & & 55 & & & 55 & \\
\hline
\end{tabular}

Table 2 depicted that there was a decrease in the anxiety levels before and after Penguin exercise on the treatment group. The mean anxiety level before treatment was 19.636 with the Standard Deviation (SD) 6.022 while after treatment, the mean declined to 12.381 with the SD
4.424. Surprisingly, the mean in the control group plateaued from 14.709 to 15.163.

3. The effect of Penguin exercise on the anxiety levels of female students in the treatment and control group

Table 3. The effect of Penguin exercise on the anxiety levels of female students in the treatment and control group

\begin{tabular}{|c|c|c|c|c|c|c|}
\hline \multirow[t]{2}{*}{ Anxiety level } & \multicolumn{3}{|c|}{ Treatment group } & \multicolumn{3}{|c|}{ Control group } \\
\hline & Mean & $\mathbf{Z}$ & $p$ & Mean & Z & $\mathbf{P}$ \\
\hline $\begin{array}{c}\text { Before } \\
\text { After }\end{array}$ & $\begin{array}{l}19,636 \\
12.381\end{array}$ & $-6,339$ & 0,000 & $\begin{array}{l}14,709 \\
15,163\end{array}$ & $-1,193$ & 0,233 \\
\hline n (sample) & \multicolumn{3}{|c|}{55} & \multicolumn{3}{|c|}{55} \\
\hline
\end{tabular}

Table 3 showed that the $p$ value $(0.000)$ is $\alpha<0.050$. It means that there is a significant effect of Penguin exercise on the anxiety levels of the treatment group. In the control group, the $p$ value is 0.233 which means that the hypothesis is rejected or it means that there is no effect of SKJ on reducing anxiety levels.

\section{DISCUSSION}

\section{The Anxiety Levels of Female Students}

This study shows that most students from the sample had a moderate level of anxiety whether in the treatment or control groups. However, after applying the penguin exercise, the number of students who experienced anxiety reduced to only a mild level in both treatment and control groups, even though, in the control group only a small number increased. This study is similar to the study of Siyamti and Pertiwi (2011), which showed a correlation between PMS and anxiety with three levels of anxiety including mild anxiety (19 respondents or $17.1 \%$ ), moderate anxiety (33 respondents or $29.7 \%$ ) and severe anxiety (55 respondents or 53.2\%). Another study by Wahyuni (2014) regarding anxiety level and PMS experienced by students in Muhamadiyah I Surakarta showed that 22 of the respondents (55\%) experienced moderate
PMS symptoms and 18 of the respondents (20\%) experienced severe PMS symptoms. From those 40 respondents, it was found that 26 respondents (65\%) suffered mild anxiety, six respondents (15\%) suffered moderate anxiety and eight respondents (20\%) suffered severe anxiety.

In Lestari's study (2015), the majority of her respondents experienced moderate PMS symptoms respondents or $56.4 \%$ ) and experienced a moderate level of anxiety (32 female or $58.2 \%)$. The study that was conducted on year two female students of SMK $\mathrm{N} 1$ Bantul showed that there was a relationship between anxiety levels and PMS $(p<0.05)$ with the Kendall's tau coefficient of 0.613 (Lestari, 2015). The results of this study also correspond with the study conducted by Zaka \& Mahmood, (2012). They stated that changing lifestyle, modifying diet, exercises, stress reduction and provision of services by health providers, such as counseling by pharmacist can optimize quality of life and overall health of women suffering from PMS. 


\section{The Effect of Penguin Exercise on the} Anxiety Levels of Female Students

This study revealed that there are significant differences in the anxiety levels of students with premenstrual syndrome who were treated with penguin exercise compared to the control group who performed senam kesegaran jasmani (SKJ). In the study by Nurmiaty et al. (2011) it was proven that nonpharmacological therapy through self-care, such as diet and exercise, can prevent or relieve the symptoms of PMS. Intercultural studies which were conducted across 14 cultures in 10 different countries found that the prevalence of PMS in non-western countries, e.g. Indonesia, was lower than in western countries $(23 \pm 34 \%)$ (Nurmiaty et al., 2011). Biological factors, life style, social factors, education, economic status and stress were suspected as being the prevalent influencing factors on PMS (Nurmiaty et al., 2011).

Hawari (2001) defined anxiety as an affective problem that is signified by a deep and continuous feeling of fear or worry. Problems of reality testing ability, experiencing the splitting of personality or a personality disturbance (as long as it is in the normal ranges and that person does not have any behavioural disturbances, this is not considered to be anxiety (Hawari, 2001). A study from Susanti et al. (2017) reported that there was a significant relationship between the anxiety level during the PMS and the level of anxiety of teenagers. The more severe the PMS is, the more anxiety the teenagers experience (Susanti et al., 2017).

Women's response towards PMS may differ from one to another. Some women looked towards menstruation and PMS positively so that they accepted and prepared well for the changes caused by the PMS (Susanti et al., 2017). Lestari (2015) added that women used various coping strategies in facing PMS such as rationalisation (thinking with normal reality), relaxation through exercise or looking for support from others. The strategies were considered effective in reducing the symptoms of PMS (Lestari, 2015). The main limitation of our study was the inability to study the long-term effect of penguin exercise and reappearance of symptoms after stopping penguin exercise.

\section{CONCLUSION}

Penguin exercise can reduce anxiety levels. There was no effect on anxiety levels for the control group that were treated by SKJ $(p=0.233)$. Penguin exercise is one of the exercises that can reduce the anxiety levels of women students who experience premenstrual syndrome. Furthermore, this exercise is one of the non-pharmacological methods that can be used to help people reduce their anxiety levels during the premenstrual syndrome stage. We recommend the performance of further studies to evaluate the effect of penguin exercise in other obstetrical and gynecological cases. This is strongly needed, as well as analysing the effect of penguin exercise in reducing daily living stresses.

\section{REFERENCES}

American College Obstetricians and Gynaecologists.

Menstruation in girls and adolescents: using the menstrual cycles as a vital sign. ACOG Committee Opinion, 349.

Dehnavi, Z. M., Jafarnejad, F., \& Goghary, S. S. (2018). The effect of 8 weeks aerobic exercise on severity of physical symptoms of premenstrual syndrome: A clinical trial study. BMC Women's Health, 18(1), 1-7.

Delara, M., Ghofranipour, F., Azadfallah, P., Tavafian, S. S., Kazemnejad, A., \& Montazeri, A. (2012). Health related quality of life among adolescents with premenstrual disorders: A cross sectional study. Health and Quality of Life Outcomes, 10(1), $1-5$.

Elvira, S. D. (2010). Sindrom pramenstruasi normalkah. Jakarta: Fakultas Kedokteran Universitas Indonesia. 
Gracia, M., Wangsa, B., Agung, N., \& Sidharta, V. M. (2011). Hubungan siklus menstruasi terhadap gangguan tidur pada mahasiswi Fakultas Kedokteran Universitas Katolik Atma Jaya. Damianus Journal of Medicine, 10, 77-80.

Hawari, D. (2001). Manajemen stress, cemas dan depresi. Fakultas Kedokteran Universitas Indonesia.

Jaya, I. P. E., Karmaya, N. M., \& Jawi, M. (2018). Kebugaran fisik siswa retardasi mental ringan pelatihan senam pinguin dari pada senam ria. Sport and Fitness Journal, 6(2), 5964.

Kemenkes, R. I. (2013). Riset kesehatan dasar (Riskesdas) 2013. Kemenkes RI. Jakarta.

Kusumawati, A., \& Finurina, I., (2016). Pengaruh frekuensi konsumsi kafein terhadap sindrom premenstruasi pada mahasiswi Fakultas Kedokteran Angkatan 2013 - 2015. SAINTEKS, 13(2), 66-76.

Lestari, C. P. (2015). Hubungan sindrom pramenstruasi dengan tingkat kecemasan pada siswi kelas XI Jurusan Akutansi SMK Negeri 1 Bantul Yogyakarta. STIKES Aisyiyah Yogyakarta.

Maged, A. M., Abbassy, A. H., Sakr, H. R. S., Elsawah, H., Wagih, H., Ogila, A. I., \& Kotb, A. (2018). Effect of swimming exercise on premenstrual syndrome. Archives of Gynecology and Obstetrics, 297(4), 951-959.

Nugroho, T., \& Utama, B. I. (2014). Masalah kesehatan reproduksi wanita. Nuha Medika.

Nurmiaty, Wilopo, S. A., \& Sudargo, T. (2011). Perilaku makan dengan kejadian sindrom premenstruasi pada remaja (Eating Behavior and the Prevalence of Premenstrual Syndrome in Teenagers). Berita Kedokteran Masyarakat, 27(2), 7582.
Pawestri, D. R. (2014). Gambaran tanda dan gejala pre menstrual syndrome pada remaja putri di SMK $\mathrm{N} 9$ Surakarta. Biologi Reproduksi, 12, 15-20.

Prawirohardjo, S., Wiknjosastro, H., \& Sumapraja, S. (2011). IImu kandungan edisi ketiga. Jakarta: Yayasan Bina Pustaka Sarwono.

Ratikasari, I. (2015). Faktor-faktor yang berhubungan dengan kejadian sindrom pramenstruasi ( PMS) pada siswi SMA 112 Jakarta tahun 2015. Universitas Islam Negeri Syarif Hidayatullah Jakarta.

Ritung, D. C. N., \& Olivia, S. (2018). Hubungan stres terhadap Premenstrual Syndrome (PMS) pada mahasiswi Fakultas Kedokteran Universitas Tarumanagara Angkatan 2011. Tarumanagara Medical Journal, 1(1), 59-62.

Siyamti, S., \& Pertiwi, H. W. (2011). Hubungan antara tingkat kecemasan dengan Sindrom Premesntruasi pada mahasiswi tingkat II Akademi Kebidanan Estu Utomo Boyolali. Jurnal Kebidanan Akbid Estu Utomo, 3(1), 29-36.

Suparman, E., \& Sentosa, I. R. (2011). Premenstrual syndrome. Jakarta: EGC.

Suprayanto. (2010). Sindrom premenstruasi pada remaja. Jakarta :Rineka Cipta.

Susanti, H. D., Ilmiasih, R., \& Arvianti, A. (2017). Hubungan antara tingkat keparahan PMS dengan tingkat kecemasan dan kualitas tidur pada remaja putri. Jurnal Kesehatan Mesencephalon, 3(1), 23-31.

Wahyuni. (2014). Gambaran sindroma pramenstruasi dari gejala emosional dan fisik pada siswi SMP Muhammadiyah 1 Surakarta. PROFESI, 11, 36-40. 
Jurnal Keperawatan Soedirman 15 (2) 2020 : 31 - 38

Wijayanti, Y. T. (2015). Analisis faktor yang berhubungan dengan kejadian premenstrual syndroma pada remaja putri. Jurnal Kesehatan Metro Sai Wawai, 8(2), 1-7.
Zaka, M., \& Mahmood, K. T. (2012). Premenstrual syndrome- A review. Journal of Pharmaceutical Sciences and Research, 4(1), 1684-1691. 